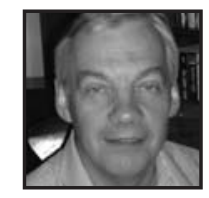

\title{
Commentary: \\ Grow Tomorrow's School Leaders? \\ Plant Some Seeds Today!
}

\author{
Julian Thompson, Leading Futures Ltd.
}

\section{ABSTRACT}

School leadership development has received significant investment in the UK in recent years. Programmes to support leaders at all levels have focussed on national standards, leadership behaviours and capacity building. England is now facing an increasing shortage of headteachers. This article provides a perspective on this situation and offers some practical ideas to school leaders for building approaches to succession planning in their own schools.

$\mathrm{n}$ this article I provide the background and some of my reflections on a major school leadership challenge in England at present. Although our educational management and administration systems are different, I know from friends and colleagues in Canada that in the main our values about learning and leading are the same. I offer the following in the hope that there may be resonances and reference points which might be helpful for school leaders and those working with them in Quebec and beyond.

England's National College for School Leadership (NCSL) is a unique institution. It is a nationally funded college that was created to identify, develop and accredit leadership at all levels in a wide range of educational settings and services. It was established in the 1990s during the New Labour government's most intense phase of intervention to raise educational standards and was set against a background of continuing research and concern about the impact of classroom practice on learners' 
basic skills. Increasing autonomy to school leaders and their governing bodies who by then had their own budgets and admission arrangements was "balanced" by rigorous national and local accountability via published tests results, league tables and school inspections. School leadership and especially headship was in the spotlight.

NCSL's first response was not to promote a delivery or interventionist model, but to consult with serving headteachers and facilitate their voices in the national debate. School networks and collaboratives were encouraged and the nature of learning communities was explored. Alongside this, a suite of subsidized programs was developed for all teachers. This covers the range from middle (subject and faculty) leadership to experienced and executive headteachers and has a strong accent on blended learning and a significant e-learning dimension. These programs have been constantly revised and adapted and are the major platform and currency for school leaders' professional development in England. A cornerstone is the National Professional Qualification for Headteachers which is a statutory requirement for those seeking a first headship. Ofsted, the national school inspection system, reported that the quality of leadership and management in schools improved significantly in the years after 2000.

Michael Fullan (2005) has pointed out the importance of enabling a voice for leaders in shaping system change, if we are to sustain improvements. Developing the conditions in which school leaders feel supported and confident to share new learning openly has been a challenge, particularly at a time when to many colleagues the national agenda has seemed over prescriptive, judgmental and too sharply focused on a narrow range of indicators. The creation of a climate which is supportive of new learning but professionally stimulating and challenging is at the heart of the NCSL's leadership learning vision. It is also a model for building leadership capacity at the school and institutional level. This has never been more important than now.

\section{The New Challenge in England}

At the start of this school year, it became clear to the government that there is a major problem in the future supply of school leaders. Statistics show that $50 \%$ of current headteachers are over 50,25\% are over 55 and about 40\% will retire by 2010 . The baby boomers are looking forward to retirement. Also, increasing numbers of successful headteachers are moving into advisory, consultancy or other roles. 
Although the recruitment of new teachers has improved, applications for headships have been falling and many posts need to be readvertised, especially in primary schools where in 2006-2007 the figure was 37\%. Between 2010 and 2012, there will a major shortage of headteachers unless countermeasures are taken now.

After the quality of the teaching, it is the quality of leadership in our schools which is the single most important factor in determining how well our pupils learn. Yet often at a local level, it is only when a vacancy occurs and a new headteacher or principal is appointed that the role or the qualities required are looked at dispassionately and in detail. It is often the only time we are really aware of the supply and quality of leaders for our schools.

The NCSL this year has been given an additional and explicit role to work in partnership with local county and city councils to build capacity and increase the quality and supply of school leaders. Materials have been developed to support schools, governing bodies and local authorities. The aim is to facilitate local solutions that will impact on both recruitment and retention in the short and long term.

\section{Planning to Succeed}

Perhaps it is worth considering how we might "grow our own" school leaders of tomorrow. There are many fine and skilful teachers in our schools whose influence should be sustained, not only on young people but also on their colleagues.

Succession planning or working strategically to identify, nurture and support leadership potential may bring other benefits. Some factors worth considering are that:

- The pace of change is accelerating. Schools need to build confidence and capacity among their staff so that everyone can respond creatively and skilfully to the needs of the future.

- The vast majority of heads say that leading a school is the most satisfying and worthwhile job they could do. This moral purpose and success should be celebrated and understood and marketed.

- Successful schools model learning not just with children but also with staff, parents and governors. Much of the learning about leadership is 
about building high quality relationships and understanding the impact of one person's behaviour on another's. Schools need good leadership everywhere and especially in the classroom.

- Succession planning can provide a framework for gathering evidence and evaluating the quality of leadership of distributed leadership. Everyone wants to work in an organization where careers and opportunities grow.

- It gives the opportunity for everyone involved in a school to share thinking about what leadership is and could be. This may well involve creative thinking about completely new models of leadership and include new agencies and professionals.

Of course, many schools and leaders are looking to the future and building teams and individuals continuously and intuitively, but the challenge remains: determining how a more coordinated approach can help good practice to spread. Just as importantly, how can a system which over recent years has tended to operate more individually build systems to support leadership capacity between and across schools? Below is a short summary of the work in progress of one community of schools.

\section{Working Strategically and in Partnership}

Bath and North East (NE) Somerset is a local authority in the southwest of England. It has 62 primary schools, 13 secondary schools and 4 special schools. In national terms it is a small local authority.

Using national succession planning funding and with support from NCSL, Bath and NE Somerset has put in place a number of initiatives:

\section{Working Directly With Leaders}

- A Headteacher Focus Group has been established to generate ideas, advise the schools, the local authority and individuals.

- An Aspiring Heads Group-around 20 deputies and other leaders who are actively looking towards headship make up a group which meets 
regularly, discusses leadership, practical aspects of recruitment and receives input from serving headteachers.

- NCSL Leadership Pathways, the nationally subsidized program for teachers aspiring to headship, was begun recently with 27 local participants and their 15 school-based coaches.

- Leadership opportunities are being created at all levels. For example, the local authority is supporting and encouraging the recruitment of teaching assistants for the Higher Level Teaching Assistant status and supporting those teaching assistants looking at qualified teacher status by signalling routes to degree status.

- A local professional framework has been put in place to link increasing leadership roles and responsibilities with relevant continuing professionnal development and performance management.

- The National Fastrack Teacher Program, an accellerated leadership program designed for classroom teachers who have shown leadership potential, is now being offered to schools.

- A number of internships will be available to enable deputy heads to spend up to a week working with a head in another school. Funding is available to cover their responsibilities in their own school.

- Colleagues with National Professional Qualification for Headship qualification who are actively looking for headships have been drawn together as a learning community with needs analysis against the National Standards for Headteacher and individual programs to support them plus tailored support through the appointment and interview process.

\section{Working With Leadership Teams, School Governors and Managers}

By looking at leadership collaboratively, school leaders and managers will play a part in building capacity across schools and communities now and in the future. Ways in which school leaders or governing boards could be involved might include: 
- Discussing the situation in a school not just in terms of vacancies and the immediate situation but in the context of the school vision and values.

- Building a culture that supports leadership development at all levels. For example, asking about coaching opportunities for staff; enquiring how a school is identifying and supporting leadership in teaching assistants and support staff and other adults who work there.

- Asking if a school provides leadership development for pupils perhaps through councils or parliaments. How successful student leaderships platformed, and if schools talk of leadership in the curriculum?

- Reviewing leadership frameworks and management structure to ensure that they are fit for a purpose which includes developing opportunities for staff.

- Discussing how a school builds a climate for personal growth and learning among staff.

- Looking at new routes to provide leadership experience, secondments, partnerships, business and professional links. Some schools may wish to establish their own leadership development program. This could be done in partnership with training providers and universities.

- Discussing and defining the qualities expected from the leadership in schools. Everyone should be involved in this.

- Talking together about how to retain staff who show the greatest potential by asking what the path to leadership progression is for them in their various departments or roles.

- Thinking about encouraging development on three levels: self, team and organizational; sharing information across schools; building a sense of a learning community which goes beyond a single institution.

There is a clear move and great interest in developing team leadership skills. This can relate to helping a school through a process which builds capacity towards the school's priorities or perhaps working through approaches to understanding how leadership behaviours can build team effectiveness. More recently the NCSL's 
Multi Agency Team Development Programme focuses on recognizing and building shared understandings between different professionals working in extended services, schools or other agencies to support children.

Succession planning is currently a nationally priority in the UK. An analysis of the demographic data has raised some difficult and deep questions not least of which is about our current systems' purpose and fitness to deliver in the longer term. Perhaps the answers lie where they always did: in trusting and empowering those who work successfully in schools to nurture the skills and release the creative potential in our learners and leaders at all levels.

\section{References}

Fullan, M. (2005). Leadership and Sustainability, System Thinkers in Action. Thousand Oaks, CA: Corwin Press.

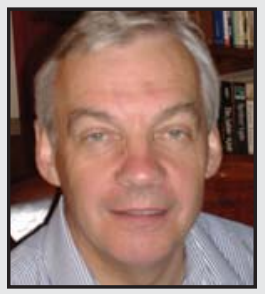

Julian Thompson has been a headteacher in two schools in the UK and until 2006 was Regional Director of the National College of School Leadership (NCSL) South West centre. He works as an independent consultant, coach and school improvement partner. He is a lead facilitator for the national Leadership Pathways programme and NCSL Team programmes. In 2005 in partnership with colleagues at McGill he established an international learning community between a group of school leaders in the UK and Quebec.

LINK TO:

www.ncsl.org.uk

www.ncsl.org.uk/tomorrowsleaderstoday

www.bestpracticenet.co.uk

www.bathnes.gov.uk 